\title{
固定式円筒シェルーデッキ系海洋構造物の地震応答特性 EARTHQUAKE RESPONSE CHARACTERISTICS OF AN OFFSHORE DECK STRUCTURE SUPPORTED BY CYLINDRICAL SHELLS
}

\author{
福住忠裕* \\ Tadahiro FUKUSUMI
}

\begin{abstract}
Dynamic response of two cylindrical shells with a deck which may be used as an offshore structure is dealt with. Taking into account interaction effects between shells and fluid, the harmonic response as well as earthquake response of the system subjected to horizontal excitation at seabed are determined. Earthquake response in time domain is determined by the inverse transforms of multiplication of transfer function and Fourier transform of input wave, and the 1995 Hyogoken-nanbu earthquake wave is adopted as input earthquake motion. When the mass of the deck becomes large, concentrated inertia force of deck is predominant compared to the distributed wave pressure, and the exisitence of the inner fluid has little effect on the dynamic responses different from the case of without a mass of deck. The effects of the shell thickness and deck mass on the earthquake responses of structure and fluid are discussed.
\end{abstract}

Keywords: offshore structure, cylindrical shell-deck system, fluid-structure interaction, earthquake response analysis, 1995 Hyogoken-nanbu earthquake wave

海洋構造物, 円筒シェルーデッキ系構造物, 流体一構造物相互作用, 地震応答解析, 兵庫県南部地震

\section{1. 序}

近年、海洋の有効利用に向けて、海上空港や海上都市の実現に 期待が高まっている。従来、海洋空間の開発は専ら埋立方式を採 ってきたが、今後は多様な海洋構造物を用いて空間開発がなされ るものと推察される。この種の海洋構造物の上部構造の重要性は もちろんのこと、それを支持する下部構造はさらに重要である。 しかし、このような上部構造物を含めた海洋構造物之流体の動的 相互作用問題に関する未検討課題はまだ多く残されている。

大楠 ${ }^{1}$ は複数の固定鉊直円柱上波の関係を流体の多重散乱場にお ける問題として解析し、さらに、任意の子午線形状をもつ鉛直軸 対称物体亡して、カラムフーチング型複合円柱浮体の解析が松井 ${ }^{2}$ 、

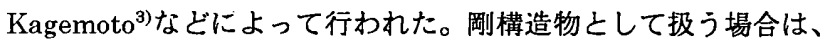
マク口的外力である波力（構造物全面での波圧積分値）が解析項 目亡なる。一方、元来構造物は弾性変形するものであり、弾性体 として扱う場合は、ミク口的外力である波王が解析の主眼となり、 この見地から登坂 ${ }^{4)}$ 、西村 ${ }^{5}$ は流体波動之 3 次元弾性体および弾性 シェルについての連成問題の定式化を示した。

1 次元弾性円柱の調和地動応答については、単一円柱の場合、 Tanaka ら ${ }^{6}$ は流体の圧縮性についての考察を行なっており、また、 Westermo ${ }^{7)}$ は複数円柱間の相互作用について、基本固有振動数で
は影響がなく 2 次の固有振動数において影響が出ると報告してい

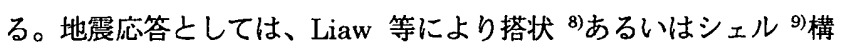
造物の逐次積分による地震応答解析法の提示之動特性の考察が行 なわれた。濱本、田中らは内部および外部流体が有る場合の固定 式円筒シェルに対するシミュレーション解析とスペクトル解析と

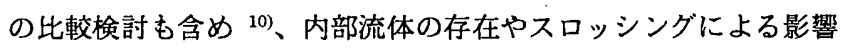
について報告を行なった ${ }^{11)}$ 。以上はすへて上部構造を持たない場 合を扱っているのに対し、筆者等は、上部構造物を有する海洋構 造物の一形態として、無限に並ぶ 1 列および 2 列円筒シェル群一 テッキ系構造物の流体調和表面波応答についての検討を行ない、 円筒構造物が弾性体でも剛体でも波圧および波力はほぼ同じであ ること、テッキが有る場合には円筒構造物面には波圧が作用する 他、構造物上端にテッキ慣性力が作用し、構造物形状が細長くテ ッキ質量が大きい時には波浪応答は地震応答と異なり相当低い振 動数を扱うものの弾性応答に共振点の現れることが有ることを報

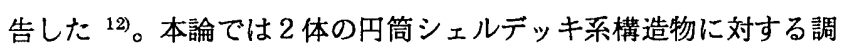
和地動応答を求め、円筒シェル間の距離、シェル板厚半径比 (シ エル剛性）およびテッキ質量の違いが波压および円筒シェルの変 形と応力の応答に及ぼす影響について考察すると共に、1995 年兵. 庫県南部地震時に観测された人工島での地震波を入力地震波とす

* 神戸大学工学部建設学科 助教授 $\cdot$ 博士 (工学)

Assoc. Prof., Dept. of Architecture and Civil Engineering, Faculty of Engineering, Kobe University, Dr. Eng. 
る地震応答を求め、固定式円筒シェルデッキ系構造物の動的応答 性状の解明を図るものである。

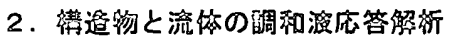

本論で地震応答解析法は周波数応答解斩による伝達関数（定常 応答解）と地震波のフーリェ変換の積を逆フーリェ変換する方法 による周波数領域での解析法である。従って地震応答解を得る上 で予め調和波応答解析による伝達閉数を求めておく必要がある。

\section{1 円筒シェルの解析}

円筒シェルは等方・等質の薄肉シェルとし、図 1 に示す通り、

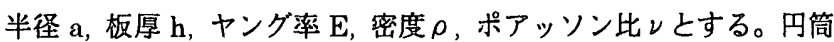
座標系 $\mathrm{x}, \theta, \mathbf{r}$ (敛直、円周、半径) 各方向の運動方程式としては 下式の通り Donnel 形の式を適用する。

$$
\begin{aligned}
& \mathrm{Nx}, \mathrm{x}+\mathrm{N} \theta \mathrm{X}, \theta / \mathrm{a}-\rho \circ \mathrm{hU}, \mathrm{tt}=0 \\
& \mathrm{~N} \theta, \theta / \mathrm{a}+\mathrm{Nx} \theta, \mathrm{x}-\rho \circ \mathrm{hV}, \mathrm{tt}=0
\end{aligned}
$$

$-\mathrm{N} \theta / \mathrm{a}+\mathrm{Mx}, \mathrm{xx}-2 \mathrm{Mx} \theta, \mathrm{x} \theta / \mathrm{a}+\mathrm{M} \theta, \theta \theta / \mathrm{a}^{2}-\rho \circ \mathrm{h}\left(\mathrm{W}+\mathrm{W}_{\mathrm{G}}\right), \mathrm{tt}-\mathrm{Ps}=0$

ただし、表示記号は下記とする。

$\mathrm{F}, \mathrm{x}=\partial \mathrm{F} / \partial \mathrm{x}, \quad \mathrm{F}, \theta=\partial \mathrm{F} / \partial \theta, \quad \mathrm{F}, \mathrm{t}=\partial \mathrm{F} / \partial \mathrm{t}$

運動方程式(1)に含まれる $\mathrm{Nx}, \mathrm{N} \theta, \mathrm{N} \theta \mathrm{x}$ は面内応力、 $\mathrm{Mx}, \mathrm{M} \theta$ と $\mathrm{M} \theta \mathrm{x}$ は曲げモーメントとねじりモータントである。これらの応力 および換算せん断力は、以下の通り変位で表される。

$$
\begin{aligned}
& \mathrm{Nx}=(\mathrm{B} / \mathrm{a})(\mathrm{aU}, \mathrm{x}+\nu \circ \mathrm{V}, \theta+\nu \circ \mathrm{W}), \\
& \mathrm{N} \theta=(\mathrm{B} / \mathrm{a})(\mathrm{a} \nu \circ \mathrm{U}, \mathrm{x}+\mathrm{V}, \theta+\mathrm{W}), \\
& \mathrm{Nx} \theta=(\mathrm{B} / 2 \mathrm{a})(1-\nu)(\mathrm{U}, \theta+\mathrm{aV}, \mathrm{x}), \\
& \mathrm{Mx}=-\left(\mathrm{D} / \mathrm{a}^{2}\right)\left(\mathrm{a}^{2} \mathrm{~W}, \mathrm{xx}+\nu \circ \mathrm{W}, \theta \theta\right), \\
& \mathrm{M} \theta=-\left(\mathrm{D} / \mathrm{a}^{2}\right)\left(\mathrm{W}, \theta \theta+\nu \circ \mathrm{a}^{2} \mathrm{~W}, \mathrm{xx}\right), \\
& \mathrm{Mx} \theta=(\mathrm{D} / \mathrm{a})(1-\nu) \mathrm{W}, \mathrm{x} \theta, \\
& \mathrm{Vx}=\mathrm{Mx}, \mathrm{x}-2 \mathrm{Mx} \theta, \theta, \\
& \mathrm{Vx} \theta=\mathrm{Nx} \theta-\mathrm{Mx} \theta / \mathrm{a}
\end{aligned}
$$

本論における減衰の扱いについては速度に関する苫性型減衰では なく、櫵造物構成材料の応力ーひずみ関係が履歷を描くことによ ってエネルギー消費を生じる履歷型であると仮定する。この場合 履歴減衰定瀿を $\mathrm{h}_{\mathrm{d}}$ とすれば、上式中のシェルの歪剛度 $\mathrm{B}$ 扰よび曲 げ㓮度 D は下記の通り複素剛性で表される。

$$
\mathrm{B}=\mathrm{Eh} \cdot\left(1+2 \mathrm{~h}_{\mathrm{d}} i\right) /\left(1-\nu^{2}\right), \quad \mathrm{D}=\mathrm{Bh}^{2} / 12
$$

$\mathrm{x}, \theta, \mathrm{r}$ 方向のシェルの変位 $\mathrm{U}, \mathrm{V}, \mathrm{W}$ は次式の通り変数分㕍形で表す。

$$
\begin{gathered}
\mathrm{U}(\mathrm{x}, \theta, \mathrm{t})=\sum_{n=0}^{\infty} \mathrm{u}(\mathrm{x})^{\circ} \cos n \theta \circ \mathrm{e}^{i \omega t}, \\
\left.\mathrm{~V}(\mathrm{x}, \theta, \mathrm{t})=\sum_{n=0}^{\infty} \mathrm{v}(\mathrm{x})\right)^{\circ} \sin n \theta \circ \mathrm{e}^{i \omega t}, \\
\mathrm{~W}(\mathrm{x}, \theta, \mathrm{t})=\sum_{n=0}^{\infty} \mathrm{w}(\mathrm{x})^{\circ} \cos n \theta \circ \mathrm{e}^{i \omega t}
\end{gathered}
$$

なお、右辺項 $u(x), v(x), w(x)$ は円周方向次数 $n$ での項である。シェ ル面に作用する流体波王 Ps（圧縮を正）および応力の例としての $\mathrm{Nx}$ も、上記変位と同樣に表される。

$$
P_{s}(\mathrm{x}, \theta, \mathrm{t})=\sum_{n=0}^{\infty} p_{s}(\mathrm{x})^{\circ} \cos n \theta \circ \mathrm{e}^{i \omega t},
$$

$$
\mathrm{Nx}(\mathrm{x}, \theta, \mathrm{t})=\sum_{n=0}^{\infty} \mathrm{nx}(\mathrm{x})^{\circ} \cos n \theta \circ \mathrm{e}^{i \omega t}
$$

$\mathrm{F}(\mathrm{x})$ 有限フーリェ Cosine と Sine 変換の定掌と像関数の表記は、

$$
\begin{aligned}
& C\{F(x)\}=\int_{0}^{H} F(x) \cos \alpha_{m} x \cdot d x=F^{c}\left(\alpha_{m}\right), \\
& S\{F(x)\}=\int_{0}^{H} F(x) \sin \alpha_{m} x \cdot d x=F^{s}\left(\alpha_{m}\right)
\end{aligned}
$$

ここに、 $\alpha_{\mathrm{m}}=\mathrm{m} \pi / \mathrm{H}$ である。偏微分方程式(1a)式に有限フーリエ Cosine 変換を、同じく(1b), (1c)式に有限フーリェ Sine 変換を施 す之、 $\mathrm{m}=0$ の時は像関数 $\mathrm{u}^{\mathrm{c}}(0)$ が単独に得られ、 $\mathrm{m}=1,2 \cdots$ の時 は下式の通りシェル変位 $\mathrm{u}, \mathrm{v}, \mathrm{w}$ の像関数 $\mathrm{u}^{\mathrm{c}}\left(\alpha_{\mathrm{m}}\right), \mathrm{v}^{\mathrm{s}}\left(\alpha_{\mathrm{m}}\right) \mathrm{w}^{\mathrm{s}}\left(\alpha_{\mathrm{m}}\right)$ に 関する 3 元連立方程式を得る。（文献 12 参照）

[A] $\left\{\mathrm{u}^{\mathrm{c}}\left(\alpha_{\mathrm{m}}\right) v^{\mathrm{s}}\left(\alpha_{\mathrm{m})}\right) \mathrm{w}^{\mathrm{s}}\left(\alpha_{\mathrm{m}}\right)\right\}^{T}=[\mathrm{B}] \quad\left(\left\{\chi_{1}\right\}-(-1)^{\mathrm{m}}\left\{\chi_{2}\right\}\right)$

$$
+\left[0, \quad 0,-a^{2} / B^{\circ} S\{p s(x)\}\right]^{T}
$$

ここに、 $[\mathrm{A}],[\mathrm{B}]$ は、振動数 $\omega$, 円周方向次数 $\mathrm{n}$, 鈶直方向 一リ土展開項数 $\mathrm{m}$ およびシェルの諸定数之寸法で表される係数マ トリックスである。 $\left\{\chi_{1}\right\},\left\{\chi_{2}\right\}$ は下記の通り、シェル上下端境 界 $(x=0, H)$ の変位と応力ベクトルであって本解の未定定数に当たる。

$$
\begin{aligned}
& \left\{\chi_{1}\right\}=\left\{\mathrm{n}_{\mathrm{x}}(0), \mathrm{v}(0), \mathrm{w}(0), \mathrm{m}_{\mathrm{x}}(0)\right\}^{T}, \\
& \left\{\chi_{2}\right\}=\left\{\mathrm{n}_{\mathrm{x}}(\mathrm{H}), \mathrm{v}(\mathrm{H}), \mathrm{w}(\mathrm{H}), \mathrm{m}_{\mathrm{x}}(\mathrm{H})\right\}^{T}
\end{aligned}
$$

逆変換によって原関数 $\mathrm{u}, \mathrm{v}, \mathrm{w}$ は次式で表され、応力も同様なフー リエ級数表現で表される。

$$
\begin{array}{r}
u(x)=\frac{1}{H}\left\{u^{c}(0)+2 \sum_{m=1}^{\infty} u^{c}\left(\alpha_{m}\right) \cdot \cos \alpha_{m} x\right\} \\
\begin{array}{r}
v(x)=\frac{2}{H} \sum_{m=1}^{\infty}\left\{v^{s}\left(\alpha_{m}\right)+\frac{1}{\alpha_{m}}\left[(-1)^{m} v(H)-v(0)\right]\right\} \sin \alpha_{m} x \\
\quad+\frac{x}{H} v(H)+\frac{H-x}{H} v(0)
\end{array} \\
\begin{array}{r}
\mathrm{w}(x)=\frac{2}{H} \sum_{m=1}^{\infty}\left\{w^{s}\left(\alpha_{m}\right)+\frac{1}{\alpha_{m}}\left[(-1)^{m} w(H)-w(0)\right]\right\} \sin \alpha_{m} x \\
+\frac{x}{H} w(H)+\frac{H-x}{H} w(0)
\end{array}
\end{array}
$$

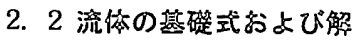

構造物の径は流体泣子運動の径にくらへて十分大きく、波高が 比較的小さいもの之すれば、非線形流体力は無視でき、微小振幅 波理論が適用できる。さらに、流体は非炶性、無渦流、非王縮性 と仮定すると、流体速度ポテンシャル理論が適用でき、流体の速 度ポテンシャル

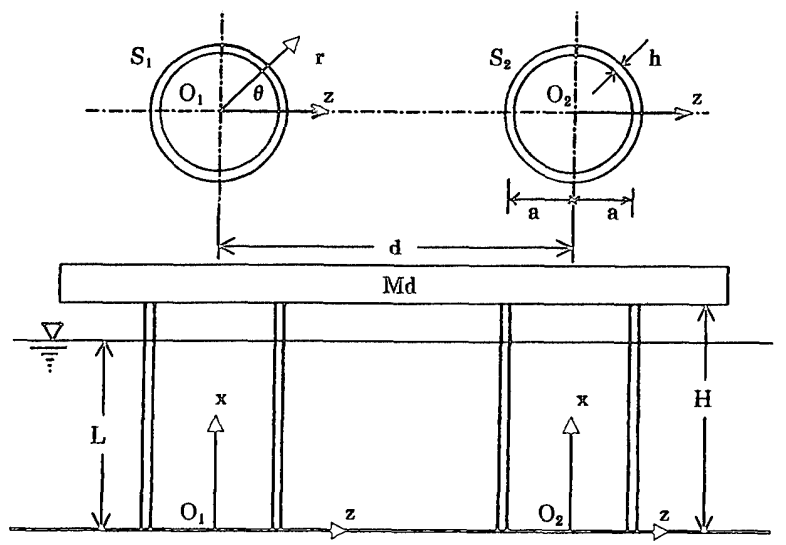

Fig.i Anatyzed model of cylindrical shalls with dech 
度ポテンシャル $\phi に$ 関する次式が流体の解析対象式となる。

$$
\nabla^{2} \phi=\phi_{, r}+\phi_{, r} / r+\phi_{, \theta \theta} / r^{2}+\phi_{, x x}=0
$$

\section{2.1 構造物内部領域におけるの速度ポテンシャル}

構造物内部領域 $\mathrm{I}(\mathrm{r} \leqq \mathrm{a})$ に対して、上端自由表面・下端鉛直方向 拘束条件を満足する水深 $\mathrm{L}$ の円筒 $\mathrm{S}_{\mathrm{i}}$ の内部流体ポテンシャル $\phi$ の 解は、局所円筒座標系 $0 \mathrm{i}\left(\mathrm{r}_{\mathrm{i}}, \theta_{\mathrm{i}}, \mathrm{x}\right)$ に関する次式で表される。

$$
\begin{gathered}
\phi_{\mathrm{i}}\left(\mathrm{r}_{\mathrm{i}}, \theta_{\mathrm{i}}, \mathrm{x}, \mathrm{t}\right)=\sum_{n=0}^{\infty} \mathrm{e}^{i n \theta i}\left\{\mathrm{~A}_{\mathrm{ni}} \cdot \mathrm{J} \mathrm{n}\left(\mathrm{k}_{0} \mathrm{r}_{\mathrm{i}}\right) \cdot \frac{\cosh \left(k_{0} x\right)}{\cosh \left(k_{0} L\right)}\right. \\
\left.+\sum_{q=1}^{\infty} \mathrm{B}_{\mathrm{nqi}} \cdot \mathrm{I} \mathrm{n}\left(\mathrm{k}_{\mathrm{q}} \mathrm{r}_{\mathrm{i}}\right) \cdot \frac{\cos \left(k_{q} x\right)}{\cos \left(k_{q} L\right)}\right\} \cdot \mathrm{e}^{i \omega t}
\end{gathered}
$$

ここに、 $\mathrm{A}_{\mathrm{ni}}, \mathrm{B}_{\mathrm{nqi}}$ はシェルと流体接触面での境界条件により決 定される未定定数。J n, In はn次の第 1 種ベッセル関数、同変 形ベッセル関数であり、 $\mathrm{k}_{0}, \mathrm{k}_{\mathrm{q}}$ は次式を満足する波数である。

$$
\omega^{2}=g \cdot k_{0} \tanh \left(k_{0} L\right), \quad \omega^{2}=g \cdot k_{q} \tan \left(k_{q} L\right)
$$

ここに、 $\mathrm{g}$ は重力の加速度である。

\subsection{2 構造物外部領域における速度ポテンシャル}

構造物外周領域 II（ $\mathrm{a} \leqq \mathrm{r})$ に対し、上記流体の上下端境界条件 及び無限遠放射条件を満足する円筒 $\mathrm{S}_{\mathrm{i}}$ の外部流体ポテンシャル の解は、

$$
\begin{aligned}
\phi_{\mathrm{ii}}\left(\mathrm{r}_{\mathrm{i}}, \theta_{\mathrm{i}}, \mathrm{x}, \mathrm{t}\right)= & \sum_{n=0}^{\infty} \mathrm{e}^{i n \theta i}\left\{\mathrm{C}_{\mathrm{ni}} \cdot \mathrm{Hn}\left(\mathrm{k}_{0} \mathrm{r}_{\mathrm{i}}\right) \cdot \frac{\cosh \left(k_{0} x\right)}{\cosh \left(k_{0} L\right)}\right. \\
& \left.+\sum_{q=1}^{\infty} \mathrm{D}_{\mathrm{nqi}} \cdot \mathrm{Kn}\left(\mathrm{k}_{\mathrm{q}} \mathrm{r}_{\mathrm{i}}\right) \cdot \frac{\cos \left(k_{q} x\right)}{\cos \left(k_{q} L\right)}\right\} \cdot \mathrm{e}^{i \omega t}
\end{aligned}
$$

ここに、 $\mathrm{C}_{\mathrm{n} i}, \mathrm{D}_{\mathrm{nq}}$ は未定定数で、 $\mathrm{Hn}, \mathrm{Kn}$ は第 2 種ハンケル関数、 第 2 種変形ベッセル関数である。他の内筒 $\mathrm{S}_{\mathrm{j}}$ の速度ポテンシャル の解 $\phi_{\mathrm{ji}}$ は、上記円筒 $\mathrm{S}_{\mathrm{i}}$ の解 $\phi_{\mathrm{ii}}$ で $\mathrm{i}$ を $\mathrm{j}$ に読替えて得られる。これ にベッセルの円筒座標変換公式を適用し、 $\mathrm{O}_{\mathrm{j}}\left(\mathrm{r}_{\mathrm{j}}, \theta_{\mathrm{j}}, \mathrm{x}\right)$ 座標系に関す る上記ポテンシャル $\phi_{\mathrm{j} j}\left(\mathrm{r}_{\mathrm{j}}, \theta_{\mathrm{j}}, \mathrm{x}, \mathrm{t}\right)$ を $\mathrm{O}_{\mathrm{i}}\left(\mathrm{r}_{\mathrm{i}}, \theta_{\mathrm{i}}, \mathrm{x}\right)$ 座標系に関する表現 に替えたものを $\phi_{\mathrm{ij}}\left(\mathrm{r}_{\mathrm{i}}, \theta_{\mathrm{i}}, \mathrm{x}, \mathrm{t}\right)$ と記号付けるものとして、

$$
\begin{aligned}
\phi_{\mathrm{ij}}\left(\mathrm{r}_{\mathrm{i}}, \theta_{\mathrm{i}}, \mathrm{x}, \mathrm{t}\right)=\sum_{n=-\infty}^{\infty} \sum_{q=0}^{\infty}(-1)^{\mathrm{n}} \mathrm{e}^{i(q+n) \beta \mathrm{ji}} \cdot \mathrm{e}^{-i n \theta i} \\
\left\{\mathrm{C}_{\mathrm{nj}} \mathrm{Hn}+\mathrm{q}\left(\mathrm{k}_{0} \mathrm{~d}_{\mathrm{ij}}\right) \operatorname{Jn}\left(\mathrm{k}_{0} \mathrm{r}_{\mathrm{i}}\right) \frac{\cosh \left(k_{0} x\right)}{\cosh \left(k_{0} L\right)}\right. \\
\left.+\sum_{q=1}^{\infty} \mathrm{D}_{\mathrm{nqj}} \cdot \mathrm{Kn}+\mathrm{q}\left(\mathrm{k}_{\mathrm{q}} \mathrm{d}_{\mathrm{ij}}\right) \operatorname{In}\left(\mathrm{k}_{\mathrm{q}} \mathrm{r}_{\mathrm{i}}\right) \frac{\cos \left(k_{q} x\right)}{\cos \left(k_{q} L\right)}\right\} \cdot \mathrm{e}^{i \omega t}
\end{aligned}
$$

ここに、 $d_{i j}$ は $\mathrm{i}, j$ 円柱原点 $0_{\mathrm{i}}-0_{\mathrm{j}}$ 間の距離， $\beta_{\mathrm{ji}}$ は $0_{\mathrm{j}}$ を始点と する直線 $0_{j}-0_{i}$ の Z 軸となす角度である。上式 $\phi_{i j}$ は $S_{i}$ 月筒に対 する $\mathrm{S}_{\mathrm{j}}$ 円筒からの寄与分に当たり、 $\mathrm{S}_{\mathrm{i}}$ の全ポテンシャル $\phi_{\mathrm{i}}\left(\mathrm{s}_{\mathrm{j}}\right.$ についても同様）は次式のように表すことができる。

$$
\phi_{\mathrm{i}}=\phi_{\mathrm{ii}}+\phi_{\mathrm{ij}}, \quad \phi_{\mathrm{j}}=\phi_{\mathrm{ij}}+\phi_{\mathrm{ji}}
$$

\section{2.3 波圧と波力の表現}

$\mathrm{S}_{\mathrm{i}}$ 円筒に作用する波圧 $\mathrm{P}_{\mathrm{Si}}$ 扩よび办平 (Z 方向) 波力 $\mathrm{P}_{\mathrm{Zi}}$ は上 記ポテンシャル $\phi_{\mathrm{i}}$ を用いて次式で表される。

$$
P_{s i}\left(\theta_{i}, x, t\right)=-i \omega \cdot \rho_{F} \phi_{i}\left(a, \theta_{i}, x, t\right)
$$

$$
P_{Z i}(t)=\int_{0}^{2 \pi} \int_{0}^{L} P_{S i}\left(\theta_{i}, x, t\right) \cos \theta \cdot a d \theta \cdot d x
$$

ここに、 $\rho_{\mathrm{F}}$ は流体の密度である。

\section{2 境界条件}

円筒表面での連続条件、シェル上下端での境界条件およびテ ッキの釣合条件は以下とする。

(1) 円筒表面、シェルと流体の半径方向速度の一致条件 ;

$$
\mathrm{W}, \mathrm{t}=-\phi, \mathrm{r} \quad(\mathrm{r}=\mathrm{a}, 0 \leqq \mathrm{x} \leqq \mathrm{L})
$$

(2) 円筒下端、固定条件 ;

$$
\mathrm{u}=0, \quad \mathrm{v}=0, \quad \mathrm{w}=0, \quad \mathrm{w}, \mathrm{x}=0 \quad(\mathrm{x}=0)
$$

テッキは剛で円筒シェル上端水平断面は円形を保持するもの とし、シェルとテッキの接合は剛節とする。また、地動入力方向 は $\mathrm{S}_{1}, \mathrm{~S}_{2} 2$ 月筒の軸心を結ぶ図 1 の $\mathrm{z}$ 方向とし、テッキの水平方 向の鈞合 $\left(\sum \mathrm{F}_{2}=0\right)$ は考慮するが、鉛直およびロッキング運動は 扱わないものとする。以上より円筒上端境界条件は下記のとおり、 フーリエ級数の次数 $\mathrm{n}$ に応じた式で表される。

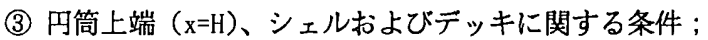

$$
\begin{aligned}
& \text { i) } \mathrm{n}_{\mathrm{x}}=0, \mathrm{v}=0, \quad \mathrm{w}=0, \quad \mathrm{w}_{, \mathrm{x}}=0 \quad(\mathrm{n}=0,2,3, \ldots) \\
& \text { ii) } \mathrm{n}_{\mathrm{x}}=0, \quad \sum \mathrm{F}_{\mathrm{z}}=\sum_{i=1}^{2} V_{z i}+V_{z D}=0, \quad \mathrm{v}=-\mathrm{w}, \quad \mathrm{w}_{, \mathrm{x}}=0 \quad(\mathrm{n}=1)
\end{aligned}
$$

ここに、 $\mathrm{V}_{\mathrm{ZD}}$ はテッキ慣性力であって $\mathrm{V}_{\mathrm{ZD}}=\mathrm{M}_{\mathrm{D}} \cdot \mathrm{W}_{\mathrm{D}, \mathrm{tt}}$ (ここに $\mathrm{M}_{\mathrm{D}}$

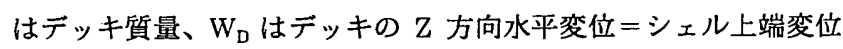
$\mathrm{w}(\mathrm{H})$ ) である。また、 $\mathrm{V}_{\mathrm{Zi}}$ は円筒 $\mathrm{S}_{\mathrm{i}}$ 上端での $\mathrm{Z}$ 方向水平力（シェ ル断面換算せん断応力の積分值)であり、

$$
V_{Z i}=\int_{0}^{2 \pi}\left[V_{X i} \cos \theta_{i}+V_{X \theta i} \sin \theta_{i}\right] a \cdot d \theta_{i}
$$

シェルおよび液体に関する以上の境界条件および連続条件に対応 して作成される複素連立方程式を解くことによって、本解に含ま れる未定定数は総て確定し、それよりシェルテッキー流体系の調 和波応答解析の結果として伝達関数が得られる。

\section{3. 数值解析と考察}

数值解析上のパラメーターとしては、シェル半径を $\mathrm{a}=5 \mathrm{~m}$ とし、 シェル高さ比 $\mathrm{H} / \mathrm{a}=5$, 水深比 $\mathrm{L} / \mathrm{H}=3 / 4$ とする。シェルの履歴減衰 定数は $\mathrm{h}_{\mathrm{d}}=0.025$ とし、鋼製を想定してヤング率は $\mathrm{E}=2.1 \times 10^{10} \mathrm{~kg} / \mathrm{m}^{2}$, ポアッソン比は $\nu=0.3$, 単位重量は $7800 \mathrm{kgf} / \mathrm{m}^{3}$ とする。シェル板 厚については、シェルには鉊直載荷荷重による軸圧縮力が作用す るほか、シェル内部に流体が存在しない場合には、外部流体によ る静水压などの外圧を受けるため座屈を考慮して板厚を設定する 必要があるが 14),15)、ここではシェル板厚比 $\mathrm{h} / \mathrm{a}=1 / 80$ を標準板厚比 として、 5 割差のある 4 ケース； $\mathrm{h} / \mathrm{a}=1 / 180,1 / 120,1 / 80,1 / 53.3$ を想 定した。デッキ質量比 $\mathrm{M}_{\mathrm{D}}$ (テッキ質量) $/ \mathrm{M}_{0}$ (長期許容引張応力に 対応する質量)には、 $0 ， 0.05 ， 0.1 ， 0.2$ の 4 段階を想定した。こ こに、 $\mathrm{M}_{0}=4 \pi$ ah $\sigma_{0} / \mathrm{g}$ であり、 $\sigma_{0}$ (長期許容引張応力度) $=1.6 \times 10^{7} \mathrm{kgf} / \mathrm{m}^{2}$ として $\mathrm{h} / \mathrm{a}=1 / 80$ の場合、 $\mathrm{M}_{0}=6.28 \times 10^{7} / \mathrm{g}(\mathrm{kgf})$ となる。 なお、デッキ質量 $\mathrm{M}_{\mathrm{D}}$ と 2 体の円筒シェル質量 $\mathrm{M}_{\mathrm{S}}(=4 \pi$ ahH $\rho)$ の比は $\mathrm{M}_{\mathrm{D}} / \mathrm{M}_{\mathrm{S}}=82 \mathrm{x}\left(\mathrm{M}_{\mathrm{D}} / \mathrm{M}_{0}\right)$ で、 $\mathrm{M}_{\mathrm{D}} / \mathrm{M}_{0}=0.05,01,0.2$ の時、 $\mathrm{M}_{\mathrm{D}} / \mathrm{M}_{\mathrm{S}}=4$, $8.2,16.4$ 倍亡なり、支持部であるシェル質量に比へ上部デッキ質量 が相当大きいモテルを想定していることになる。 


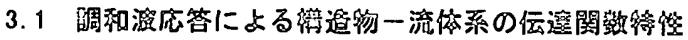

本論のシェルおよび液体の解は、フーリェ級攻とベッセル級数の 無限級数の形式となっており、結果の精度は何項まで算入するか に依存する。図 $2 \mathrm{~A}-\mathrm{a}, \mathrm{b}, \mathrm{c}$ はシェル鉛直方向フーリエ級数項数を $\mathrm{m}=10$,

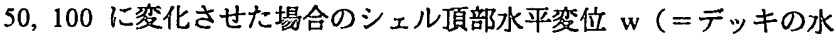
平桨位）、下端垂直応力 $\sigma_{x}$, 外部流体の水深 $1 / 2$ におけるシェル 面波圧 $\mathrm{P}_{\mathrm{SII}}$ の伝達関数（計算パラーターターは $\mathrm{M}_{\mathrm{D}} / \mathrm{M}_{0}=0.05, \mathrm{~d}_{12} / \mathrm{a}=6$, $\mathrm{n}=0 \sim 2, \mathrm{q}=1 \sim 3$ に設定し、横軸刻み $\Delta \omega=5 \mathrm{rad} / \mathrm{s}$ 間隔でプロット) の結果である。 $\mathrm{m}=50$ で結褁は $\mathrm{m}=100$ での結果に殆ど同じである ことが分かる。図 2B-a,b はそれぞれシェル流体連成系の 1 次と 2 次の固有振動数 $\left(\omega_{1}, \omega_{2}\right)$ における同上伝達関数の值を、フーリ 工級数項数 $\mathrm{m}$ (刻み $\Delta \mathrm{m}=10$ 項間隔) を横軸にして示したものであ り、 $m=50$ 項程でほぼ收束していることが分かる。図 3A,B は同様 に円周方向フーリェ展開次数 $\mathrm{n}$ を変化させた場合の図である。た
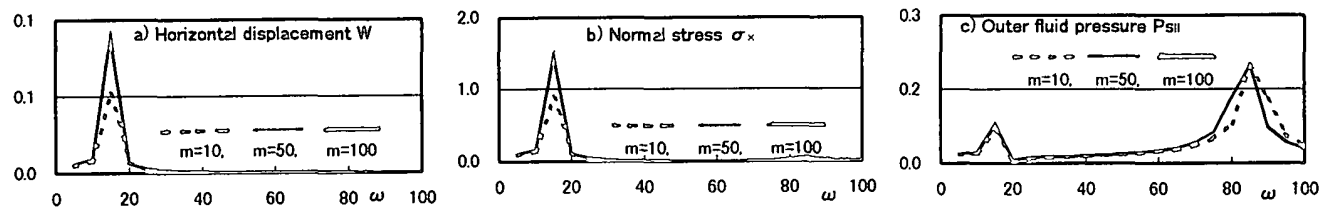

Fig.2A Frequency responses(a'osolute value) for differemi number of tems of $m$ of Fourier expansion of shell
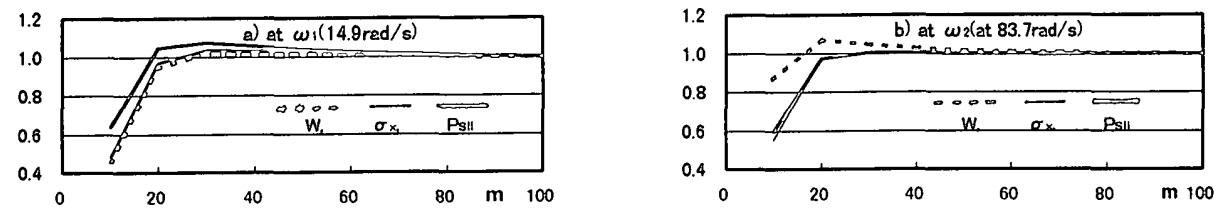

Fig.28 Variation of responses(absolutic value) with number of tems $m$ of Fouriar expansion of shell
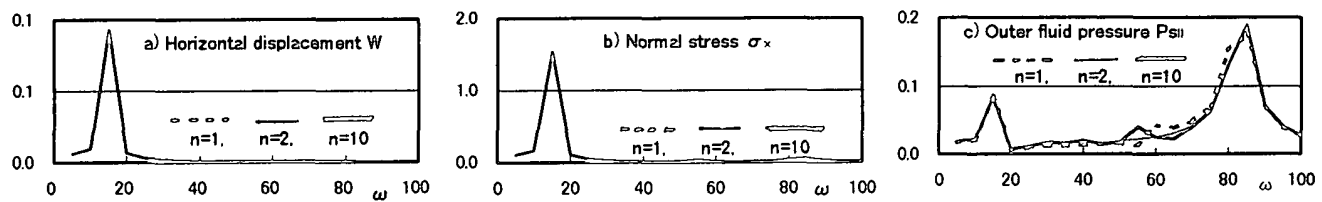

Fig.3A Frequency responses (a'osolute value) for diffieremi number of tems of $n$ in circumferential direction
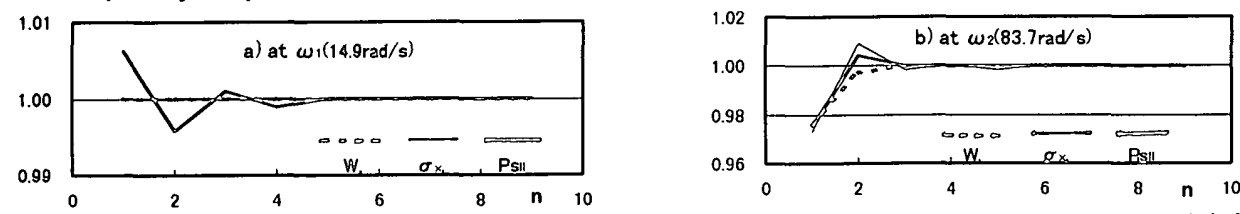

Fig.3B Variation of responses (absolute value) with number of iems of $n$ in circumfierential direction
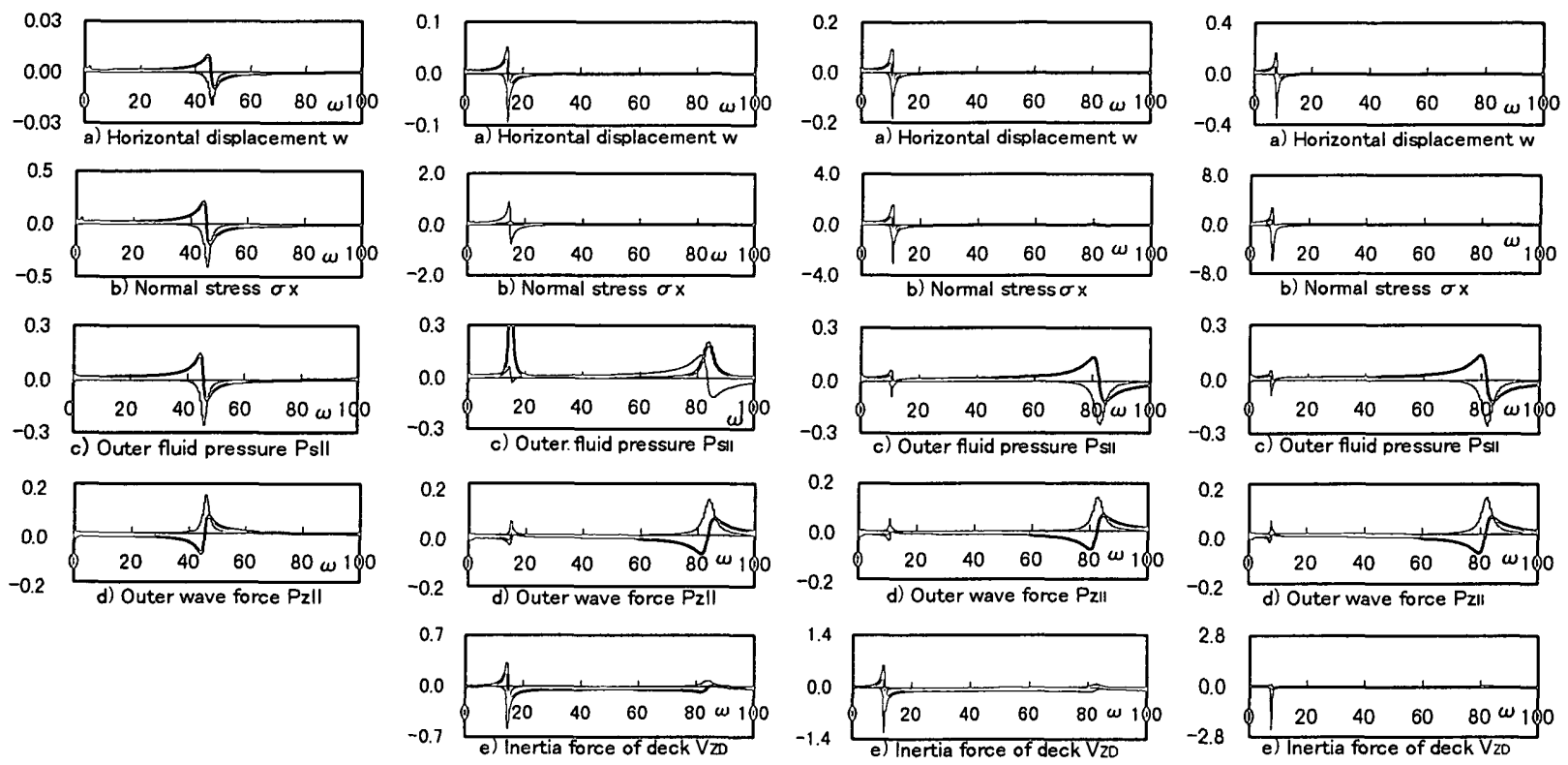

A) $M M_{D} / M_{0}=0$

B) $M M_{D} / M_{0}=0.05$

C) $M M_{D} / M_{0}=0.1$

D) $M_{D} / M_{0}=0.2$

Fig. F Frequency response curves of displacememi w and nomal siress $\sigma_{x}$ of the shell, ourter Ruid pressure $P_{S I}$, wave force $P_{Z I}$ and ineritia force $V_{Z F}$ for different deck mass ratio of $M I_{D} / M A_{0}=0,0.05,0.1,0.2$ 


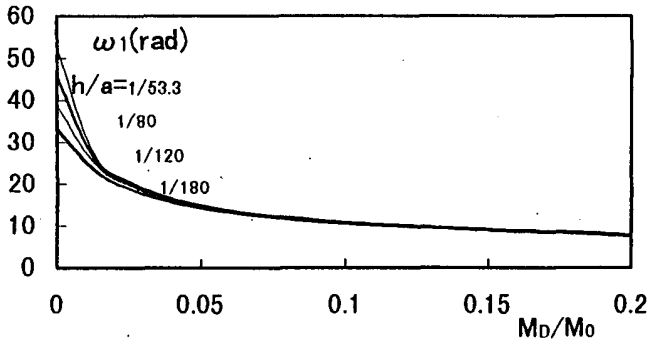

A) $\omega_{1}$ versus mass ratio $M_{D} / M_{0}$

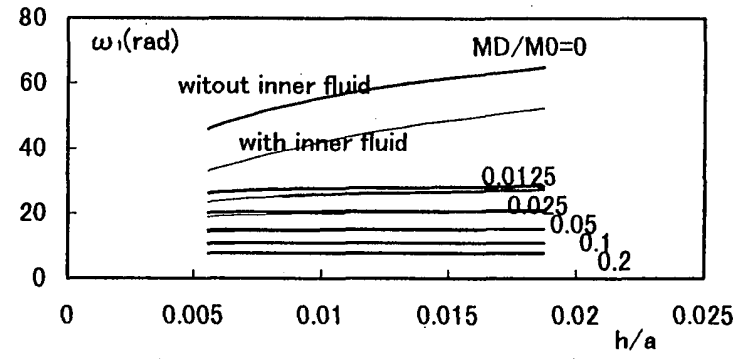

B) $\omega_{1}$ versus thickness ratio $h / a$

Fig.5. First natural frequency $\omega_{1}$ versus deck mass ratio $M_{D} / M_{0}$ and thickness ratio $h / a$

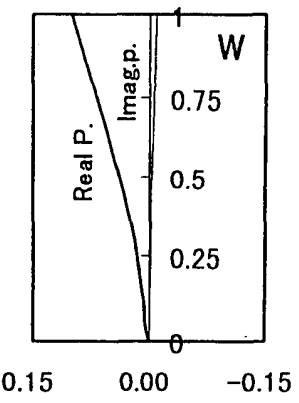

A) first natural frequency $\omega_{1}=14.9(\mathrm{rad} / \mathrm{s})$
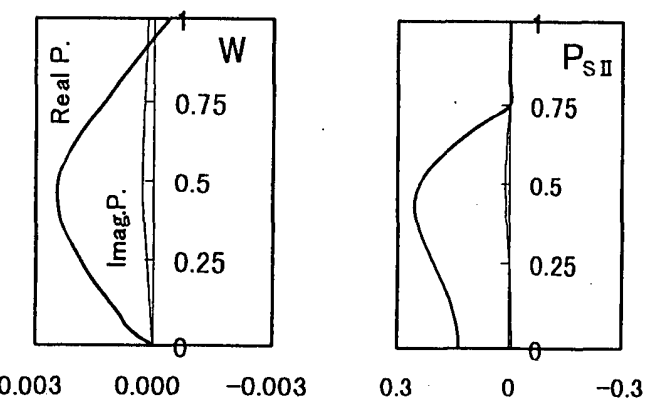

B) second natural frequency $\omega_{2}=83.7(\mathrm{rad} / \mathrm{s})$

Fig.6 Mode shapes of horizontal displacement of shell $W$ and outer fluid pressure $P_{\mathrm{SI}}$ acting on the shell

だし、中心間距離比 $\mathrm{d}_{12} / \mathrm{a}=6$ では $\mathrm{n}$ による変化が見られないので、 $\mathrm{d}_{12} / \mathrm{a}=3$ とした時の結果である。波压はシェルの変位や応力に比べ て次数 n による収束がやや遅いと見られる。以上のような検討に もとづき、1 次や 2 次固有振動数といった主要振動数において、 多数項を採って得られる最終的な值に対して $3 \%$ 程度の䛇差に収 まるように、 $\mathrm{m}=0 \sim 50, \mathrm{n}=0 \sim 2$, 流体の波数は $\mathrm{q}=1 \sim 3$ を採って以 下の計算を行なった。

図 $4 \mathrm{~A} \sim \mathrm{D}$ は 4 段階の質量比における各種伝達関数 $\mathrm{H}(\omega)$ (上述

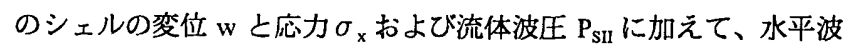
力 $\mathrm{P}_{\mathrm{ZII}}$ およびデッキ慣性力 $\mathrm{V}_{\mathrm{ZD}}$ ) の結果であり、海底面で単位振幅 の調和水平加速度入力に対する応答である。なお、横軸刻みは $\Delta$ $\omega=0.307 \mathrm{rad} / \mathrm{s}$ 間隔で 85 点、 $\Delta \omega=0.614 \mathrm{rad} / \mathrm{s}$ 間隔で 120 点、全体で $\omega=100 \mathrm{rad} / \mathrm{s}$ まで 205 点を採ってプロットしている。また、図示に おいては下記無次元化量を用いており、シェルの垂直応力 $\sigma_{x} お よ$ び曲げ応力 $\sigma_{b x}$ は、材料の短期許容応力度 $\left(=1.5 \sigma_{0}=2.4 \times 10^{7} \mathrm{kgf} / \mathrm{m}^{2}\right)$ を基準値として、また、波圧 $\mathrm{P}_{\mathrm{S}}$ はシェル下端静水圧で、波力 $\mathrm{P}_{\mathrm{Z}}$ 及 びテッキ慣性力 $\mathrm{V}_{\mathrm{ZD}}$ はシェル外周流体の静水圧の積分值で除して いる。

$$
\begin{array}{ll}
\sigma_{\mathrm{bx}}=\mathrm{M}_{\mathrm{x}} /\left(1.5 \sigma_{0} \mathrm{z}_{\mathrm{s}}\right), & \sigma_{\mathrm{x}}=\mathrm{N}_{\mathrm{x}} /\left(1.5 \sigma_{0} \mathrm{~h}\right), \quad \mathrm{P}_{\mathrm{S}}=\mathrm{P}_{\mathrm{S}} /\left(\mathrm{L} \cdot \mathrm{g} \rho_{\mathrm{F}}\right), \\
\mathrm{P}_{\mathrm{ZF}}=\mathrm{P}_{\mathrm{ZF}} /\left(\pi \mathrm{aL} \mathrm{L}^{2} \cdot \mathrm{g} \rho_{\mathrm{F}}\right), & \mathrm{V}_{\mathrm{ZD}}=\mathrm{V}_{\mathrm{ZD}} /\left(\pi \mathrm{aL}^{2} \cdot \mathrm{g} \rho_{\mathrm{F}}\right)
\end{array}
$$

ここに、 $\mathrm{z}_{\mathrm{S}}$ (断面係数) $=\mathrm{h}^{2} / 6$ である。

シェル流体連成系の 1 次固有振動数 $\omega_{1}$ (伝達関数のピーク振動 数として決定している) は、図 4 中の 4 段階のテッキ質量比に対 して、 $\omega_{1}=46,14.9,10.7,7.7(\mathrm{rad} / \mathrm{s})$ である。質量比が 0 以外、すなわ ち $\mathrm{M}_{\mathrm{D}} / \mathrm{M}_{0}=0.05,0.1,0.2(=1: 2: 4)$ の場合は、 $\omega_{1}{ }^{2}=222,114,58(=1.0$ : 0.57: 0.26）となっており、大略 $\omega_{1}{ }^{2}$ は質量に反比例する関係になっ

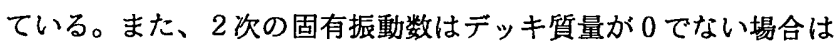
$\omega_{2}=80 \sim 90 \mathrm{rad} / \mathrm{s}$ 程度になっている。シェルの変位・応力およびテ
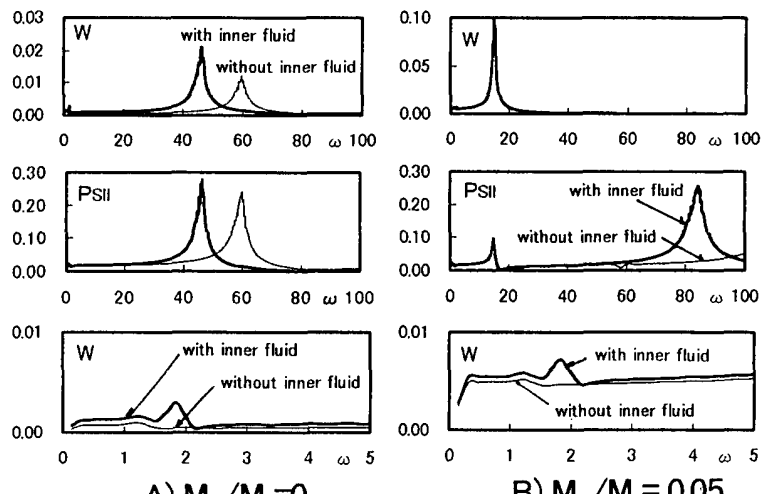

B) $M_{D} / M_{0}=0.05$

Fig.7 Difference of responses of displacement $W$ of the shell and outer fluid pressure $P_{S I I}$ by existence of inner fluid

ッキ慣性力の伝達関数の 1 次固有振動数でのピークは結果的には 凡そテッキ質量比に比例する値となっているか、２次のピークは 非常に小さく殆ど見られない。一方流体の 2 次の波圧および波力 は 1 次に対して 3 倍程度で、質量比に関係なく同程度の大きさ之 なっている。デッキ慣性力の 1 次固有振動数でのピークは波力に 比へて 1 オーダー大きい。揭載図は履歴減衰 $\mathrm{h}_{\mathrm{d}}=0.025$ での結果て あるが、減衰はピーク振動数のごく近辺における振幅だけに影響 し、ピーク値はほぼ $1 / h_{d}$ となることを確認した。

図 $5 \mathrm{~A}$ はデッキ質量比 $\mathrm{M}_{\mathrm{D}} / \mathrm{M}_{0}$ と連成系の 1 次固有振動数 $\omega_{1}$ 之の 関係を、板厚比をパラメータとして描いたものである。質量比が 0 に近い時にはシェル板厚の相異に応し、固有振動数の変化があ るのに対して、質量比がおよそ 0.02 以上の場合はシェル板厚によ る変化は殆ど無い。図 5B には、シェル板厚比 h/a と1 次固有振動 数 $\omega_{1}$ の関係を示すか、内部流体存在有無の違いも示している。内 部流体が存在しなければ固有振動数は一般的に高くなるが、テッ 
キ質量比 $\mathrm{M}_{\mathrm{D}} / \mathrm{M}_{0}$ が 0 若しくは 0 に極めて近い場合、内部流体の有 無の違いにより固有振動败に差異を生じる。

図 6 はシェルの水平変位 $\mathrm{w}$ と外部流体波压 $\mathrm{P}_{\mathrm{SII}}$ の 1 次と 2 次の固 有振動数付近でのモードである。シェルの変位は 2 次では 1 次に 対して烆違いに小さく、一方、波圧は1次より2 次の方が大きい。

図 7A,B はテッキ質题の無い場合之有る場合のシェルの変位之内 外流体波圧の伝達関数の振幅を示す。テッキ質量が無い場合には、 シェルの変位も流体の波压も内液の有無によって結果が異なって いる。これに対してデッキ質量がある場合には、シェルの変位は 内液の有無によって変わっていないか、、流体波压は 1 次固有振動 数付近では同じであるものの高振動数域で異なっている。なお、 図 7 の最下段 (シェル变位の伝達関数) は、 $\omega=5 \mathrm{rad} / \mathrm{s}$ 以内の低振 動数域の拡大図であり、 $\omega=1.9(\mathrm{rad} / \mathrm{s})$ に内部液体のスロッシングに よるピークが見られる。なお、この值がスロッシングの卓越振動 数の理論値に一致することは確認済である。

図 8 はシェル中心間距離比 $\mathrm{d}_{12} / \mathrm{a}$ (シェル中心間距離／半径）の 変動に対する伝達関数の変化を示すものである。1 次固有振動数の 時について云えば、中心間距離比が 2,3 では単一の時の応答值に 比へてそれぞれ 10\%,2\%程度小さくなるという差がある。振動数 が高い時ほどシェル間の相互作用は大きく現われ、2 次固有振動数 の時には中心間距離比 2,3 でそれぞれ 40\%,10\%程度の差之なる。 中心間距離比が 4 以上では単一の場合にほぼ同じとなりシェル間 の相互作用は現れなくなる。

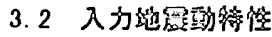

解析対象とする地霞入力波として、1995 年兵庫県南部地霞時に

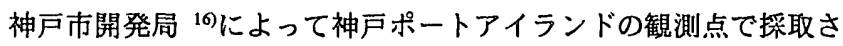
れた地震波の内、G.L.-32m 地点での南北成分水平地露波を用いる
こととし、これを図 9 に示す。この 30 秒間の震動中においてピー クが発生するのは約 4.5 秒後であり、加速度最大值は $543 \mathrm{~cm} / \mathrm{sec}^{2} 、$ 速度、変位の最大值はそれぞれ約 $60 \mathrm{~cm} / \mathrm{sec} 、 30 \mathrm{~cm}$ である。図 10 は 同上波形の加速度、速度、変位のフーリェスペクトルである。変位 スペクトル上には、 $\omega=0.31 \mathrm{rad} / \mathrm{s}$ で最初のピークが見られるほか、 これに続いて、変位スペクトル上においては $\omega=0.62,1.23,1.53,2.0$, $3.4,5.2(\mathrm{rad} / \mathrm{s})$ 程度までのピーク振動数が, 加速度スペクトル上にお いてはさらに高振動数の 6.1, 7.1, 7.5, $8.7(\mathrm{rad} / \mathrm{s})$ などにピーク振動数 が存在している。

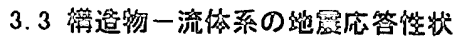

図 11 は、0〜0.2の4段階のテッキ質量比について、構造物－流 体系の各種伝達関数 $\mathrm{H}(\omega)$ と入力加速度波形（図 9a）のフーリェ変 換 $\mathrm{F}(\omega)$ との積 $\mathrm{H}(\omega) \circ \mathrm{F}(\omega)$ のフーリェスペクトルを示している。 シェル (頂部変位 $\mathrm{U}, \mathrm{W}$ 、下端応力 $\sigma_{\mathrm{x}}, \sigma_{\mathrm{bx}}$ ) の応答も流体（水梁 $1 / 2$ での波圧、水平波力）の応答も質量比の大きさに応じて大きくなっ ており、大抵は各々の 1 次固有振動数において最大之なっている。 流体の波圧および波力は内部之外部でほぼ同量之なっているが、ス ロッシング振動数 $(\omega=1.9 \mathrm{rad} / \mathrm{s})$ の時には、内部流体は外部流体に 対して 2〜3 倍に大きくなっている。シェルの鉑直変位 U は水平変 位 $W$ に比へて $1 / 5$ 程度であり、シェル下端垂值応力 $\sigma_{\mathrm{x}}$ と同曲げ応 力 $\sigma_{b x}$ はほぼ同量となっている。

地震応答解析では入力加速度最大值を $500 \mathrm{~cm} / \mathrm{sec}^{2}$ とし、入力波 形のフーリエ変換 $\mathrm{F}(\omega)$ 之、伝達関数 $\mathrm{H}(\omega)$ には $\omega=0 \sim 100(\mathrm{rad} / \mathrm{s})$ ま での振動数領域を考虑に入れて得られた各理時刻歴応答結界を図 12 に示す。A 図はテッキ質量のない場合で、他の場合に比へて系 の 1 次固有振動数 $\left(\omega_{1}=46 \mathrm{rad} / \mathrm{s}\right)$ が相当高いこ之を反映した状況が 現れている。B から D 図は質量比が 0.05 0.2 の場合の結果であっ
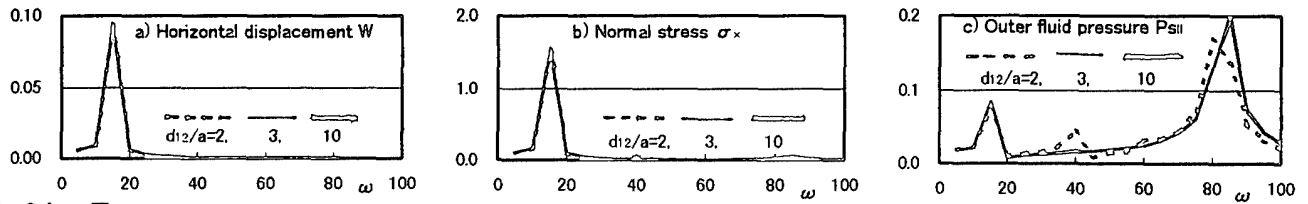

Fig.8A Frequency responses(absolute value) for dinferent ratio of distance of two shells to radius, $d 12 / a$
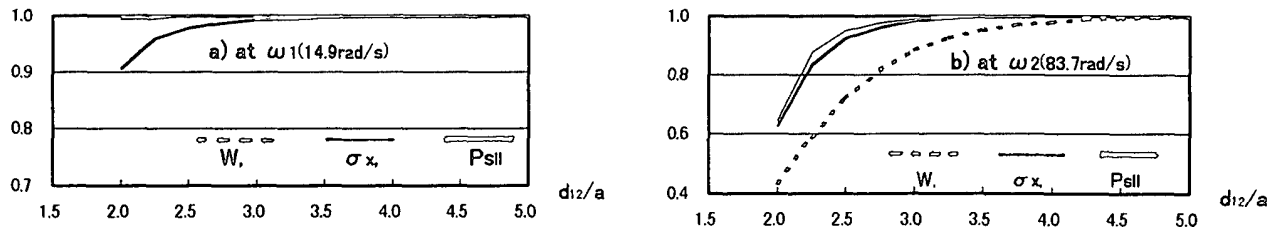

Fig.8B Variation of responses (absolute value) with ratio of distance of two shells to radius, o112/a
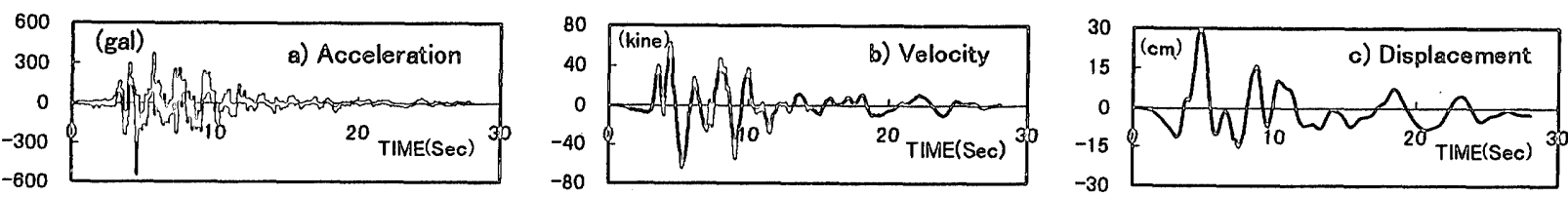

Fig.9 In-purt earchousake wave (Kobe Port Island, NS, GL-32m, 1995)
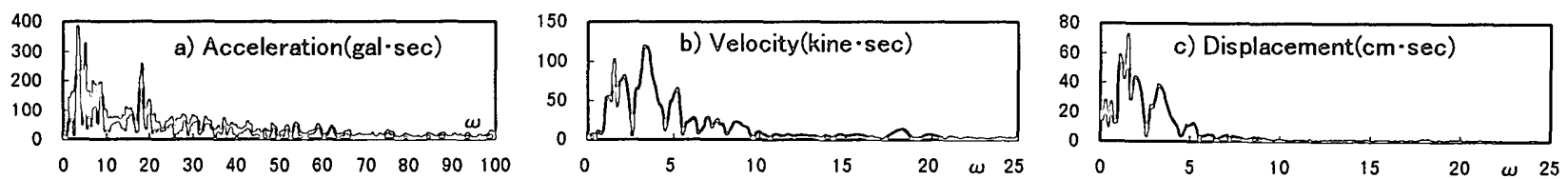

Fig.10 Fourier spectum of earthquake wave (Kobe Port Island, NS, GL-32m, 1995) 

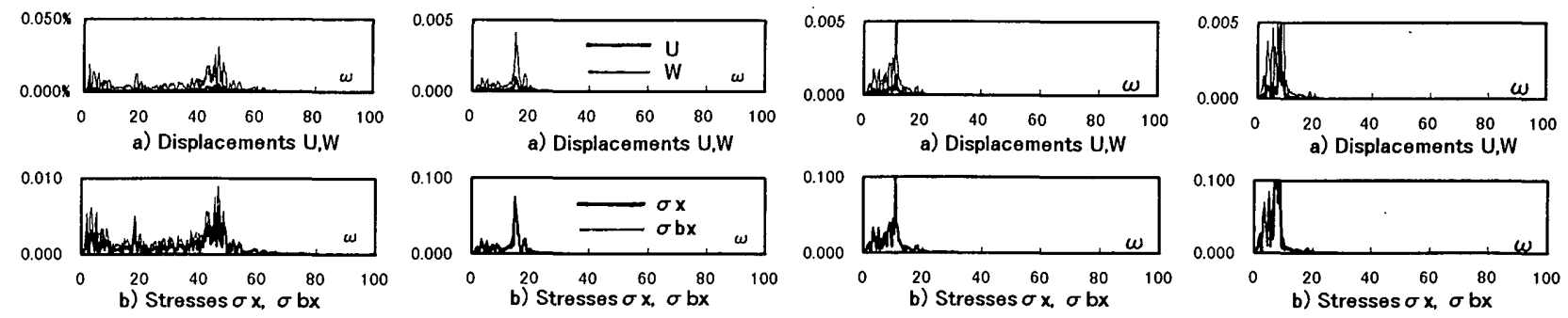

b) Stresses $\sigma \mathrm{x}, \sigma \mathrm{bx}$
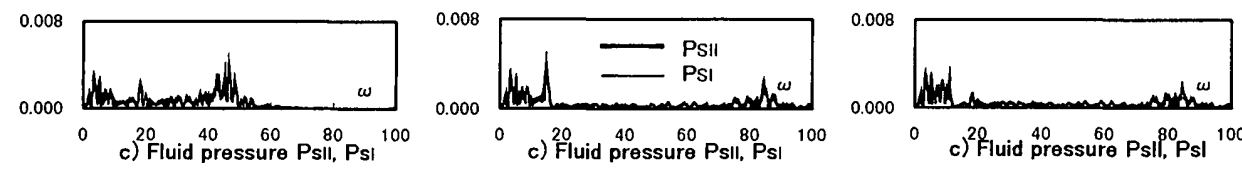

b) Stresses $\sigma \times, \sigma$ bx
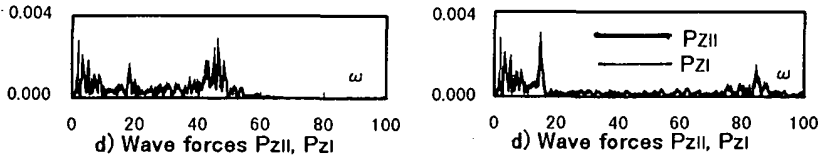

c) ${ }^{20}$ Fuid pressure Psli, Psi ${ }^{40}$
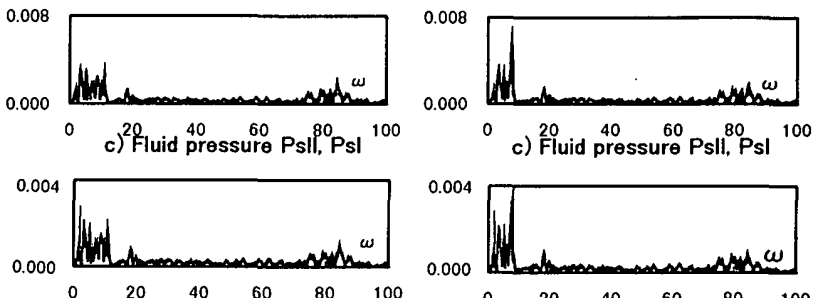

c) Fluid pressure Psll, Psl
A) $M_{D} / M_{0}=0$
B) $M_{D} / M_{0}=0.05$
C) $M_{D} / M_{0}=0.1$

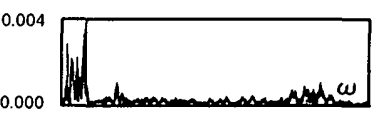

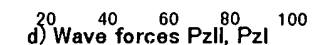

Fig.11 Fourier spectrum of displacement $w$ and normal stress $\sigma_{x}$ of the shell , fluid pressure $P_{S}$ and wave force $P_{Z}$ for different deck mass ratio $M_{D} / M_{0}$

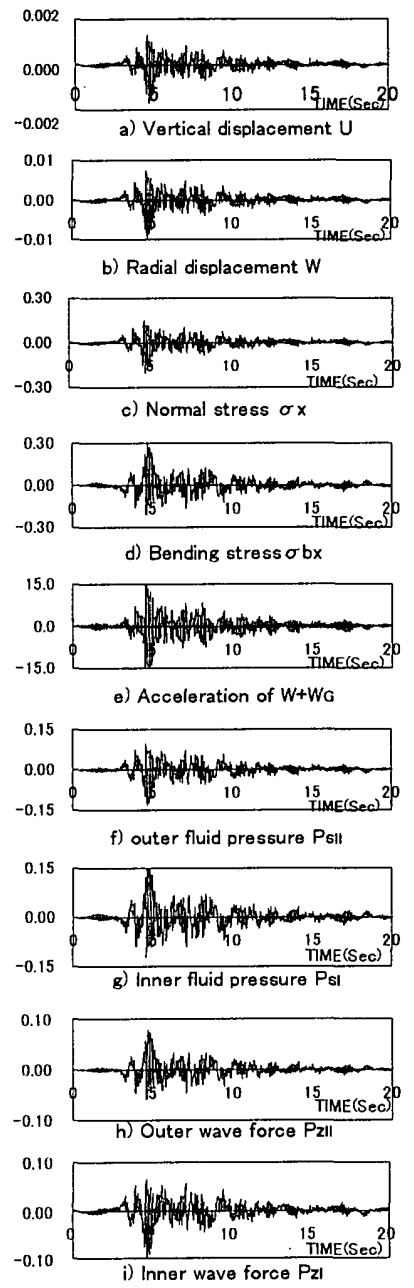

A) $M_{0} / M_{0}=0$
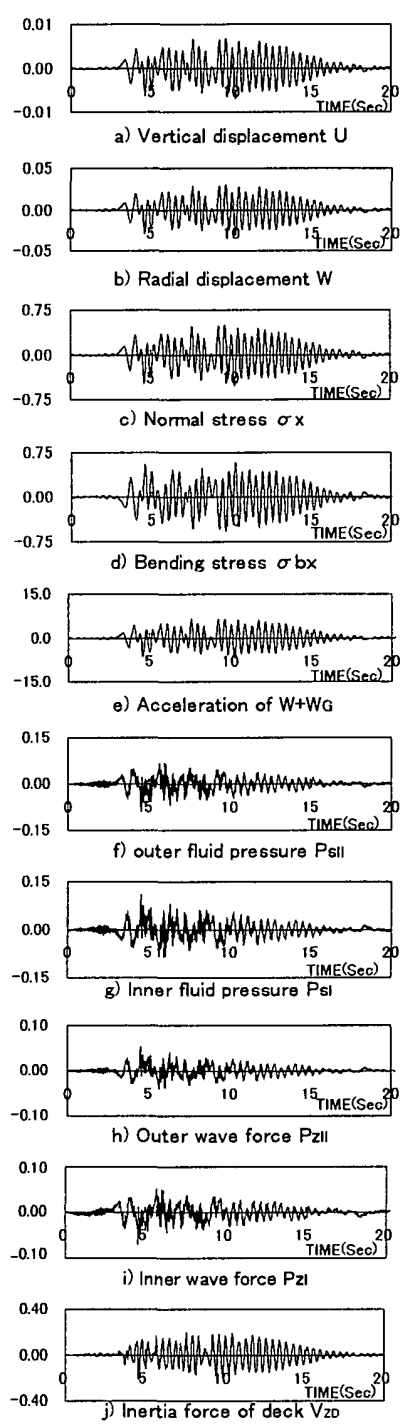

B) $M_{D} / M_{0}=0.05$
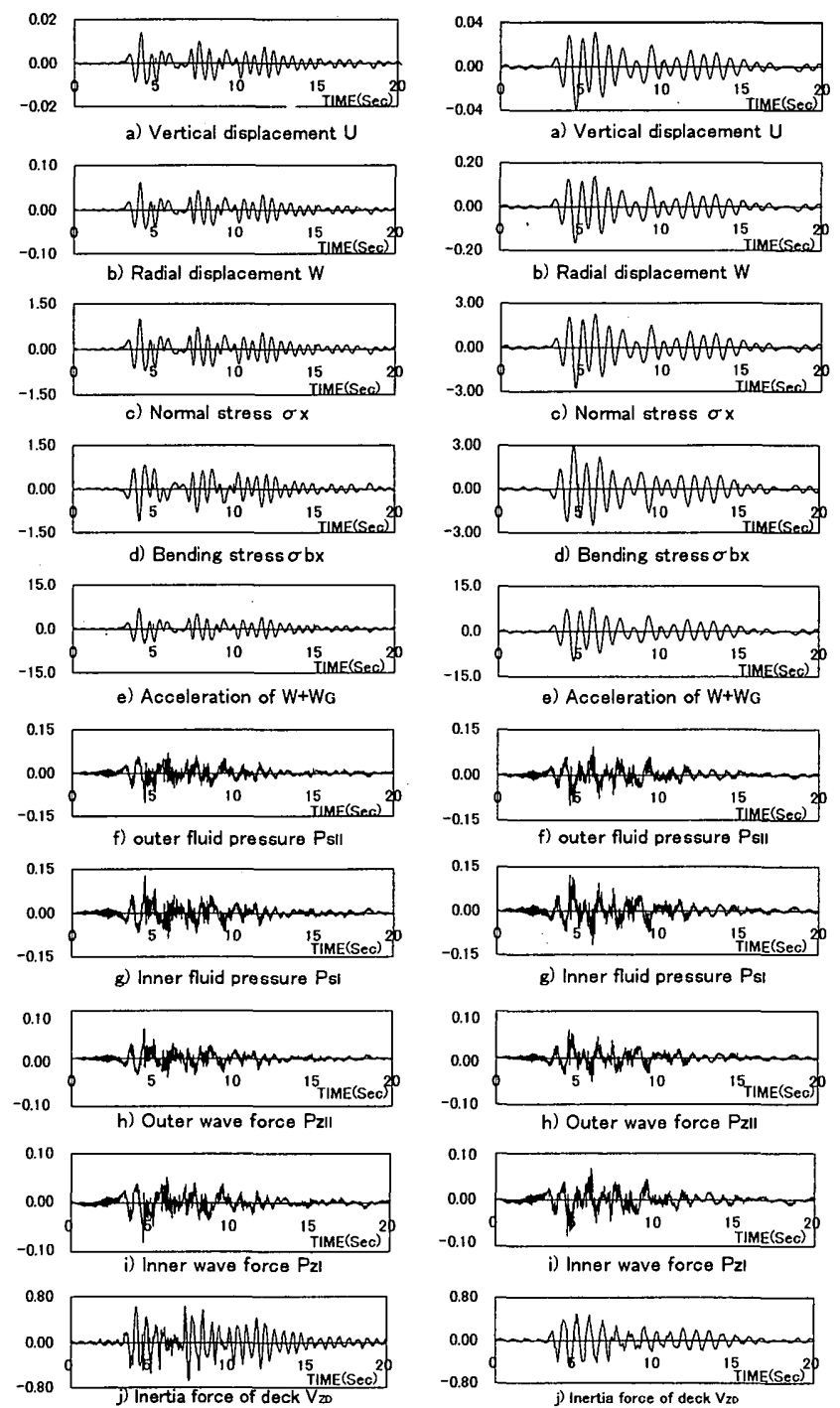

C) $M_{D} / M_{0}=0.1$

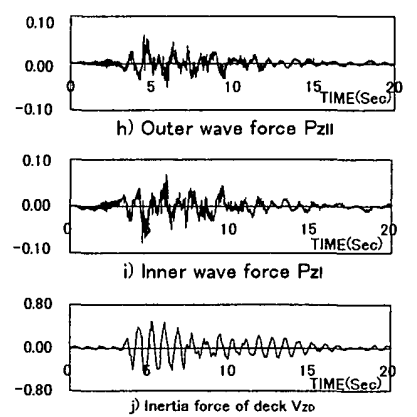

D) $\mathrm{M}_{\mathrm{D}} / \mathrm{M}_{0}=0.2$

Fig.12 Time histories of displacements $U$ and $W$, normal stress $\sigma_{x}$, bending stress $\sigma_{b x}$, horizontal acceleration of the shell, fluid pressure $P_{S}$, wave force $P_{Z}$ and inertia force $V_{Z F}$ for different deck mass ratio $M_{D} / M_{0}$ 
て、図 4 に示したようにシェルの伝達関数の掦合は $10 \mathrm{rad} / \mathrm{s}$ 付近の 1 次固有振動㥢での振幅に比へて $80 \sim 90 \mathrm{rad} / \mathrm{s}$ 付近の 2 次固有振動 数での振幅は殆ど0に近く、これを反映して時刻歷応答曲線には 2 次の成分は出なくなっている。これに対して流体の波圧および波力 の伝達関数の堨合は、図 11 に示したフーリェスペクトル $\mathrm{H}(\omega)$ 。 $\mathrm{F}(\omega)$ においても、2 次固有振動数付近の勢力は、1 次固有振動数付 近での勢力に比へて小さいものの、相当な勢力を有していることに より、時刻歷応答曲線はシェルに比へて振動数の高い波形が現れる 結果となっている。シェルの殂位と応力応答は、デッキ質量が0の 場合に最も小さく、質量の増大につれて大きくなっている。テッキ 頂部の最大水平変位応答はテッキ質量比が $0 \sim 0.2$ に対して $\mathrm{W}=0.01 \mathrm{~m} \sim 0.15 \mathrm{~m}$ 程度で、傾斜角としてはW/H=1/2500 1/150 程度 となっている。一方シェルの絶対水平加速度応答 $\left(\mathrm{W}+\mathrm{W}_{\mathrm{G}}\right)$,t はテ ッ丰質量が 0 の場合に約 $1500 \mathrm{gal} て ゙$ 最も大きく加速度応答倍率とし ては約 3 倍であり、また、テッキ質量のある場合は 1.5 倍程度であ

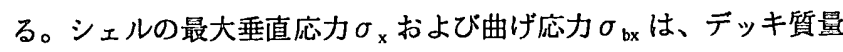
比が 0.1 でほぼ許容応力度程度となっている。内外流体の最大波压 $\mathrm{P}_{\mathrm{SI}}, \mathrm{P}_{\mathrm{SII}}$ はシェル下端に生じる最大静水圧の 1 割积度で、内外流体 波力和の最大応答は静的外周水圧積分値の 1 割程度であり、静水圧 に比へては小さい応答となっている。これに対してテッキ慣性力 $\mathrm{V}_{\mathrm{ZD}}$ は既述の通り、流体の応答亡異なり 2 次の成分が殆ど含まれな いか、静的外周水圧瑟分值の 0.2 0.6 程度で比較的大きい。なお、 内部および外部流体波压は、完全に同位相でシェル壁に作用してい ることを確認した。

\section{4. 結睔}

本論では 2 円筒シェル上に剛体テッキを有する固定式海洋構造 物の、調和地動応答および地震応答について考察した。

2 円筒シェル中心間距離については次のことが分かった。振動 数が高い時ほどシェル間の相互作用は顕著に現われ、2 次固有振動 数の時には中心間距離比 2,3でそれぞれ 40\%,10\%程度の差となる。 中心間距離比が 4 以上では単一の場合にほぼ同じとなりシェル間 の相互作用は現れなくなる。

テッキ質量および内部流体の有無に関しては次のようにまとめ られる。冈筒シェル上端にテッキ質量の無い場合、シェルには分 布力タイプのシェル慣性力と波圧が作用し、内部流体の有無は直 接波圧の有無に関わり、調和波応答特性（固有振動数や振幅）お よび地霞応答特性に影響する。一方、テッキ質量が有る場合、シ エルには上述の分布慣性力と波圧の他に上端集中カタイプのテッ キ惯性力が作用する。デッキ質量が大きくテッキ慣性力が波力に 比へて大きくなる場合にはいわゆるトップヘビーな構造形態とな り、内部流体の有無すなわち内部流体波圧の有無が円筒シェル構 造物の応答に及ぼす影響度は小さくなる。また、シェル内外部共 に流体が存在する場合は、内外の静水压のバランスがとれ静的応 答を解消出来て構造的に有利と言える。

地震応答に関しては、本論では地霞応答解析にフーリェスペク トル法を用いることによって、構造物－流体系の伝達関数特性と と地震動のフーリェスペクトル特性の 2 つ要因が地雱応答特性 を決定するということを明示できたものと考える。ここでは入力 地震動は最大加速度 $500 \mathrm{gal}$ に基準化した 1995 兵庫県南部地霞に
限定しているが、地震応答性状としては以下の事柄が分かった。 シェルには 2 次の応答は出難いのに対し、流体には 2 次の応答も 現われ、流体の波王あるいは波力の地震応答波形はシェルに比べ て高振動数の波形が出現すること、また、地震応答最大值につい ては、テッキ質量の無い場合、シェルの加速度応答は大きく 3 倍 程度の増幅倍率であるが応力応答は小さいこと、テッキ質量の増 加に応じてシェルの変位と応力応答は増大する結果となるか、質 量比が 0.1 の場合、傾斜角は $1 / 300$ でシェルの応力応答は許容応力 程度になる。以上、固定式円筒シェルーテッキ系構造物の調和地 動応答及び地震応答について、2 円筒シェル中心間距離、シェル板 厚（剛性）、デッキ質量および円筒シェル内部流体の存在の有無 の違いが、応答に及ぼす影響について考察し、固定式円筒シェル テッキ系構造物の動的応答性状の解明を図った。

\section{䀣辟}

本研究の遂行にあたり、研究のベース構築に貢献頂いた䒷天義久 神戸大学名誉教授、日下部㢣神戸大学教授、野添久視広島工業大 学助教授、(株)竹中工務店 田中洋氏に記して厚く謝意を表します。

\section{參穹立献}

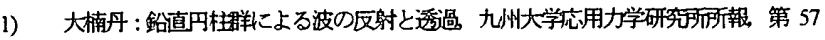
号, pp.527-544, 1982.10

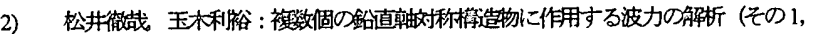

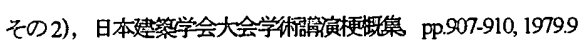

3) H.Kagemoto and D.K.P.Yue: Interactions among multiple three dimensional bodies in water waves: An exact algebraic method, J. Fluid Mech., Vol.166, pp.189-209, 1986

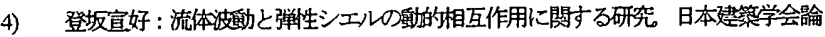
文報告集 第314 号, pp.176-183, 1982.4

5）西村敏雄：3次元弾性体及びシエルとと流体波動との連成問題に対する定式化とそ

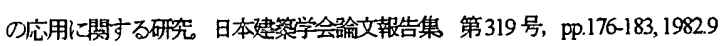

6) Y.Tanaka and RT.Hudspech: Restoring forces on vertical circular cylinders forcod by earthquakes, Earthquake Eng, Struct Dym, Vol.16, pp.99-119,1988

7) BD.Wetermo: Dynamic response of elastic cylinders in fluid layer, Vol 107, J. EM1, ASCE, pp.187-205, 1981.2

8) Liaw,C.Y.\& Chopra,A: Earthquake analysis of axisymmetric towers partially submerged in water, Joumal of Earthquake Engineering and Structural Dynamics, Vol3. pp.233-248, 1975

9) THamamoto, N.Konishi and Y.Tanaka: Surty on dynamic behaviors of shell type offshore towers dring earthquake, Proc. of the $5^{\text {th }}$ Japan Eathquake Enginering Symposium, PP.10411048,1978

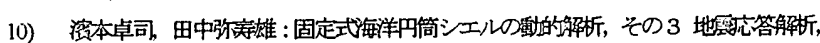
日本建筑学会的文報告集 第303 号, pp.141-154, 1981.5

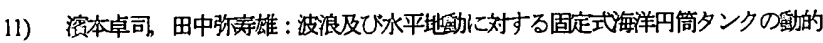

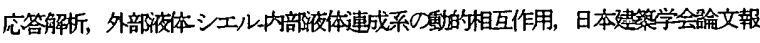
告集 第324号, pp.154166, 1983.2

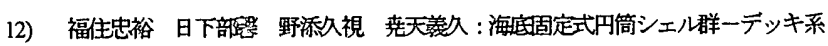

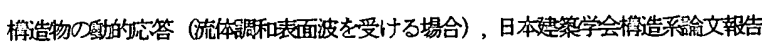
崇, 第449号,pp.185-194, 1993.7

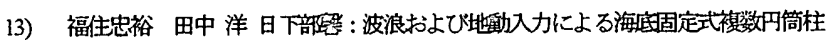
応答性状 第9回日本地窟工学シンポジウム,pp.1297-1302, 1994

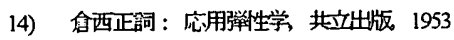

15) Stephen P. Timoshenko and James M Gere: Theory of Elastic Stability, MoGraw-Hall, 1961

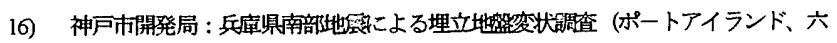
甲アイランド）報告宫，1995

(1997年 9 月 10 日原稿受理，1998年 1 月 16 日採用決定） 